ElementerIs: Jurnal Ilmiah Pendidikan Dasar Islam

Volume 2 Nomor 1 Mei 2020

e-ISSN: 2655-6324

\title{
RESPON SISWA TERHADAP PENGGUNAAN MODUL TEMATIK DALAM MENINGKATKAN KEMAMPUAN BERPIKIR KRITIS
}

\author{
Ummu Khairiyah $^{1}$, Silviana Nur Faizah ${ }^{2}$ \\ ${ }^{1}$ Universitas Islam Lamongan, ${ }^{2}$ Universitas Islam Lamongan \\ e-mail: 1 ummukhairiyah@unisla.ac.id , 2 silviana nurfaizah@unisla.ac.id
}

Diterima: 14 November 2019 I Direvisi: 27 Februari 2020 I Disetujui: 16 Mei 2020 (C) 2020 Pendidikan Guru Madrasah Ibtidaiyah Fakultas Agama Islam Universitas Islam Malang

\begin{abstract}
Abstrak
This research aimed to determine students' responses to the use of thematic modules based on the integration of Islam and science in improving critical thinking skills on energy themes and their changes in 3rd grade MI Salafiyah Kutukan Blora. The research method apply in this research is descriptive research. The Descriptive research used in this research is the survey. The research instrument used was a student response questionnaire. Analysis of student response questionnaires showed that $80,3 \%$ of students stated that using thematic modules could improve students' critical thinking skills.
\end{abstract}

Keywords: student response, thematic modules, critical thinking skills.

\begin{abstract}
Abstrak
Penelitian ini bertujuan untuk mengetahui tanggapan siswa terhadap penggunaan modul tematis berdasarkan integrasi Islam dan sains dalam meningkatkan keterampilan berpikir kritis pada tema energi dan perubahannya di MI Salafiyah kelas 3 Kutukan Blora. Metode penelitian yang digunakan dalam penelitian ini adalah penelitian deskriptif. Penelitian deskriptif yang digunakan dalam penelitian ini adalah survei. Instrumen penelitian yang digunakan adalah angket respon siswa. Analisis kuesioner respons siswa menunjukkan bahwa 80,3\% siswa menyatakan bahwa menggunakan modul tematik dapat meningkatkan keterampilan berpikir kritis siswa.
\end{abstract}

Kata kunci: respons siswa, modul tematik, keterampilan berpikir kritis.

\section{Pendahuluan}

Pembelajaran merupakan fenomena kompleks yang dipengaruhi oleh beberapa faktor, salah satunya yakni pengajaran. Seseorang akan belajar dari apa yang diajarkan padanya (Huda, 2014). Keberhasilan siswa dalam belajar salah satunya ditentukan oleh kompetensi yang dimiliki guru dalam ketepatan

This work is licensed under Creative Commons Attribution Non Commercial 4.0 International License Available online on: http://riset.unisma.ac.id/index.php/je 
menggunakan metode dalam pembelajaran. Semakin tepat metode yang digunakan, diharapkan semakin efektif dalam pencapaian tujuan pembelajaran. Salah satu metode yang tepat yakni dengan menggunkan bahan ajar dalam pembelajaran. Menurut Saglam (2011) dengan adanya bahan ajar membuat guru lebih mudah menyampaikan informasi yang ingin disampaikan dengan lebih tepat, jelas, dan mudah dupahami sehingga mempermudah siswa dalam menerima konsep yang disampaikan.

Sari (2017) dalam penelitiannya mengungkapkan bahwa penggunaan bahan ajar dalam proses pembelajaran akan menghasilkan respon yang baik bagi siswa. Hidayati (2013) menyatakan bahwa respon muncul karena ada objek yang diamati oleh panca indra dan dapat berupa pendapat yang dianggap baik jika memenuhi syarat rasional.

Siswa mempunyai tingkat kemampuan pemahaman materi yang berbedabeda, sehingga diperlukan bahan ajar yang bisa membuat siswa belajar secara mandiri. Padmapriya (2015) menyatakan satu diantara cara pencapaian pembelajaran mandiri yaitu dengan menggunakan modul. Modul merupakan bahan ajar yang disusun secara sistematis dan menarik mencakup isi materi, metode dan evaluasi yang dapat digunakan secara mandiri untuk mencapai tujuan pembelajaran sesuai tingkat kompleksitasnya.

Beberapa penelitian menyatakan bahwa penggunaan modul dalam pembelajaran berdampak positif, diantaranya penelitian yang dilakukan Sujiono \& Widiyatmoko (2014) yang menyatakan bahwa hasil belajar siswa dengan menggunakan modul mencapai 80,34 \% dengan ketuntasan klasikal kelas 100\%. Penelitian juga dilakukan Asfiah, et, al (2013) bahwa terjadi peningkatan hasil belajar siswa menggunakan modul, yaitu semua siswa (100\%) telah mencapai KKM yang ditetapkan. Selain itu, Windarti (2015) juga menyatakan bahwa respon siswa terhadap penggunaan modul dalam pembelajaran memenuhi kategori minimal baik dengan persentase banyak siswa yang menilai baik melebihi $80 \%$. Berdasarkan penelitian di atas, menunjukkan bahwa modul dapat digunakan sebagai bahan ajar bagi guru maupun siswa selain buku teks maupun LKS. Keunggulan modul dibandingkan dengan buku teks yaitu adanya komunikasi dua arah, struktur yang jelas, bahasa yang sederhana, dan memotivasi (Syahroni, M.W., Dewi, N. R., 2016).

Pelaksanaan pembelajaran di sekolah dasar sebagaimana yang dituntutkan oleh kurikulum 2013 yakni pembelajaran tematik. Keterampilan berpikir kritis bisa ditumbuhkan melalui pembelajaran tematik, dengan pembelajaran tematik, serangkaian kompetensi pembelajaran di kelas rendah sekolah dasar akan tercapai 
juga. Siswa yang memiliki kemampuan berpikir kritis dapat merumuskan pertanyaan, mempelajari masalah secara sistematis, inovatif dan dapat menghadapi berjuta tantangan dengan cara terorganisir (Men, 2017).

Berdasarkan hasil wawancara dengan guru kelas II di Madrasah Ibtidaiyah Salafiyah Kutukan Blora, diperoleh informasi bahwa siswa sulit menerima materi yang dijelaskan oleh guru sehingga minat bertanya tentang materi yang diajarkan kurang. Hal tersebut dikarenakan oleh beberapa faktor, salah satunya guru hanya menggunakan buku tematik yang berasal dari pemerintah sebagai satu-satunya sumber belajar siswa, dan belum digunakannya sumber belajar lain yang mampu melatihkan kemampuan berpikir kritis siswa sesuai dengan taraf berfikir siswa kelas rendah. Selain itu, dalam penyampaian materi, guru lebih banyak menggunakan metode ceramah karena peserta didik mengalami kesulitan menerima materi jika tidak dengan metode ceramah. Akibatnya kemampuan berpikir kritis siswa tidak terlatih.

Pengembangan kemampuan berpikir kritis pada siswa perlu dilakukan. Hal ini bertujuan agar siswa terlatih dalam menyelesaikan suatu permasalahan yang dihadapi dan mampu menyaring informasi yang diperoleh, apakah informasi tersebut benar atau salah (Muh Tawil, 2013).

Berdasarkan pernyataan tersebut lembaga madrasah ibtidaiyah menjadi perlu untuk menggunakan bahan ajar yang sesuai untuk mencapai tujuan lembaga dan kurikulum 2013 yaitu dengan menggunakan Modul tematik berbasis integrasi Islam dan Sains. Pada modul tematik berbasis integrasi Islam untuk mencapai tujuan pembelajaran yang telah ditentukan siswa disuguhi ayat al-Qur'an yang diintegrasikan dengan materi pembelajaran pada tema Energi dan Perubahannya dengan beberapa kegiatan yang dapat melatih kemampuan berpikir kritis siswa. Di dalam modul, siswa memperoleh petunjuk belajar mengenai apa yang sedang dipelajari, siswa dapat menilai sendiri tingkat pemahamannya terhadap suatu materi menggunakan alat evaluasi yang tersedia serta mengetahui tindak lanjut yang harus dilakukan oleh siswa. Tujuan dari penelitian ini adalah untuk mengetahui respon siswa terhadap modul tematik dalam meningkatkan kemampuan berpikir kritis siswa.

\section{Metode}

Bentuk penelitian yang diterapkan dalam penelitian ini adalah penelitian deskriptif. Sampel dalam penelitian ini adalah siswa kelas III Madrasah Ibtidaiyah Salafiyah Kutukan Blora yang berjumlah 21 siswa. Instrument yang digunakan berupa angket yang telah divalidasi dengan hasil validasi bahwa instrument layak 
digunakan. Bentuk angket yang digunakan adalah angket tertutup. Angket yang berisikan 9 Item pertanyaan dengan 2 jawaban iya atau tidak.

Analisis angket diperoleh berdasarkan langkah-langkah berikut:

1. Setiap jawaban yang diberikan oleh siswa, dihitung skornya. Dalam penelitian ini skor 1 diperoleh jika siswa menjawab Ya, skor 0 jika siswa menjawab tidak.

2. Merekapitulasi skor yang diperoleh tiap siswa

3. Menghitung presentasi skor yang dihitung dengan menggunakan rumus

$$
\text { Persentase }=\frac{\text { jumlah siswa yang menjawab }}{\text { jumlah seluruh siswa }} \times 100 \%
$$

4. Menentukan kriteria interpretasi skor tiap item pernyataan dengan kriteria(Riduwan, 2013)

Tabel 1. Interpretasi skor

\begin{tabular}{ll}
\hline Persentase & Kategori \\
\hline $0-20 \%$ & Sangat lemah \\
\hline $21-40 \%$ & Lemah \\
\hline $41-60 \%$ & Cukup \\
\hline $61-80 \%$ & Kuat \\
\hline $81-100 \%$ & Sangat kuat \\
\hline
\end{tabular}

5. Menginterpretasikan rata-rata skor respon siswa berdasarkan kriteria interpretasi skor

\begin{tabular}{ll}
\multicolumn{2}{l}{ Tabel 2 Kriteria respon siswa } \\
\hline Persentase & Kategori \\
\hline $85 \% \leq \mathrm{RS}$ & Sangat positif \\
\hline $70 \% \leq \mathrm{RS}<85 \%$ & Positif \\
\hline $50 \% \leq \mathrm{RS}<70 \%$ & Kurang positif \\
\hline $\mathrm{RS}<50 \%$ & Tidak positif \\
\hline
\end{tabular}

\section{Hasil dan Pembahasan}

Respon merupakan kecenderungan seseorang untuk melakukan sikap tertentu baik itu yang bersifat positif maupun negatif. Pada penelitian ini akan dilihat respon siswa setelah menggunakan modul tematik yang diukur menggunakan angket yang diisi oleh siswa. Adapun hasil angket respon siswa dapat dilihat pada Tabel 3 berikut: 
Tabel 3. Hasil Respon Siswa

\begin{tabular}{clcc}
\hline \multirow{2}{*}{ No } & \multicolumn{1}{c}{ Pernyataan } & \multicolumn{2}{c}{$\begin{array}{c}\text { Persentase } \\
\text { Jawaban }\end{array}$} \\
\cline { 3 - 4 } & & Ya & Tidak \\
\hline 1 & $\begin{array}{l}\text { Saya menerima informasi tentang } \\
\text { materi dengan mudah }\end{array}$ & $100 \%$ & $0 \%$ \\
\hline 2 & $\begin{array}{l}\text { Saya dapat menyimpulkan suatu } \\
\text { masalah dengan baik }\end{array}$ & $86 \%$ & $14 \%$ \\
\hline 3 & $\begin{array}{l}\text { Saya menjadi lebih berani dalam } \\
\text { menanyakan tentang materi }\end{array}$ & $81 \%$ & $19 \%$ \\
\hline 4 & $\begin{array}{l}\text { Saya menjadi lebih aktif dalam } \\
\text { proses pembelajaran }\end{array}$ & $71 \%$ & $29 \%$ \\
\hline 5 & $\begin{array}{l}\text { Dengan menggunakan modul } \\
\text { tematik saya bisa menjelaskan } \\
\text { tentang energy dan perubahannya }\end{array}$ & $86 \%$ & $14 \%$ \\
\hline 6 & $\begin{array}{l}\text { Dengan kegiatan orientasi saya } \\
\text { mengetahi tujuan dari } \\
\text { pembelajaran materi energi dan } \\
\text { perubahannya }\end{array}$ & $71 \%$ & $29 \%$ \\
\hline 7 & $\begin{array}{l}\text { Dengan adanya suatu masalah saya } \\
\text { dapat menyelesaikan dengan cara } \\
\text { berpikir kritis }\end{array}$ & $67 \%$ & $33 \%$ \\
\hline 8 & $\begin{array}{l}\text { Dengan saya mencari informasi, } \\
\text { kemampuan berpikir kritis saya } \\
\text { meningkat }\end{array}$ & $81 \%$ & $19 \%$ \\
\hline Rata-rata & $80,3 \%$ & $19,7 \%$ \\
\hline
\end{tabular}

Berdasarkan tabel 3 menunjukkan bahwa respon siswa rata-rata 80,3\% merespon bahwa dengan kategori positif. Artinya siswa merespon bahwa dengan menggunakan modul tematik berbasis integrase islam dan sains dapat meningkatkan kemampuan berpikir mereka.

Pada item pertanyaan pertama, persentase skor diperoleh sebesar $100 \%$. Hal ini menunjukkan bahwa modul tematik yang digunakan mampu membantu siswa dalam menerima materi dengan mudah. Modul tematik yang diterapkan yakni modul tematik yang mengintegrasikan islam dengan sains berbasis inkuiri. Menurut Anam (2016) pembelajaran yang berbasis inkuiri mempunyai keunggulan yakni (1) siswa berperan aktif dalam menemukan konsep-konsep penting; (2) Open ended topic, yaitu siswa bisa belajar melalui berbagai sumber, misal pengalaman dan lingkungan sehari-hari dengan tema yang tidak terbatas; (3) Intuitif, imajinatif, dan inovatif maksudnya siswa dapat belajar dengan mengerahkan dengan seluruh potensi yang mereka miliki, mulai dari kreatif hingga imajinasi; (4) peluang menemukan penemuan misalnya dengan observasi 
dan eksperimen. Melalui keempat hal tersebut siswa akan mendapatkan hasil dari materi yang mereka pelajari. Sedangkan Houston dan Howson (1992) (dalam Wena, 2009)mengemukakan modul pembelajaran meliputi serangkaian aktivitas yang bertujuan mempermudah siswa untuk mencapai seperangkat tujuan pembelajaran.

Item pertanyaan kedua, persentase skor diperoleh sebesar 86\%, dengan kategori respon sangat positif. Hal tersebut menunjukkan dengan penggunaan modul tematik integrase islam dan sains dapat memudahkan siswa dalam menyelesaikan masalah. Pengajaran dengan menggunakan modul memberi kesempatan kepada siswa untuk eksplorasi dalam memecahkan masalah sesuai dengan latar belakang pengetahuan dan kebiasaan dari masing-masing individu. Selaras dengan pernyataan Wahidin (Mahanal, 2007) yang menyatakan bahwa salah satu keuntungan dari pembelajaran yang menekankan pada proses keterampilan berpikir kritis adalah siswa akan memiliki kemampuan memecahkan masalah baik pada saat proses belajar mengajar dikelas maupun dalam menghadapi permasalahan nyata yang akan dialaminya.

Pertanyaan item ketiga didapatkan persentase 81\% dengan kategori positif. Hal ini menunjukkan dengan penggunaan modul tematik ini dapat membuat siswa lebih aktif bertanya. Menurut Filsaime (2008) kemampuan berpikir kritis bisa meningkat apabila siswa aktif bertanya saat berdiskusi dan bekerja secara kooperatif. Sedangkan pertanyaan item keempat diperoleh persentase $71 \%$ dengan kategori positif. Hal tersebut membuktikan bahwa kemampuan berfikir kritis siswa meningkat. Fisher (2008) menyatakan kemampuan berpikir kritis dapat memicu keaktifan siswa.

Pertanyaan item kelima sampai kedelapan diperoleh rata-rata respon siswa dengan kategori positif. Hal tersebut membuktikan bahwa dengan menggunakan modul tematik integrasi islam dan sains dapat meningkatkan kemampuan berpikir kritis siswa. Seseorang dikatakan berpikir kritis apabila mampu menunjukkan kecakapan mengidentifikasi masalah yang signifikan, menganalisis argumen, mengevaluasi dengan membandingkan kebenaran dari interpretasi, menemukan unsur-unsur yang diperlukan dalam membuat kesimpulan, memberikan penjelasan yang meyakinkan, dan membuat keputusan dari hasil yang diperoleh (Filsaime, 2008).

\section{Simpulan}

Respon siswa terhadap modul tematik berbasis integrasi islam pada sub tema energi dan perubahannya mendapatkan persentase rata-rata dengan kriteria 
positif. Hal tersebut membuktikan bahwa dengan menggunakan modul tematik dapat meningkatkan kemampuan berpikir kritis siswa.

\section{Daftar Rujukan}

Anam. (2016). Pembelajaran Berbasis Inkuiri Metode dan Aplikasi. Yogyakarta: Pustaka Pelajar.

Asfiah, N., Mosik, \& Purwantoyo, E. (2013). Pengembangan Modul IPA Terpadu Konstektual Pada Tema Bunyi. Unnes Science Education Journal, 2(1), 188195.

Filsaime, D. K. (2008). Menguak Rahasia Berpikir Kritis Dan Kreatif. Jakarta: PRestasi pustakaraya.

Fisher, A. (2008). Berpikir Kritis Sebuah Pengantar. Jakarta: Erlangga.

Hidayati, N. dan M. H. N. (2013). Respon Guru dan Siswa Terhadap Pembelajaran Permainan Bolavoli yang Dilakukan dengan Pendekatan Modifikasi (pada Siswa Kelas V SDN Wateswinagun I Sambeng- Lamongan). Jurnal Pendidikan Olahraga Dan Kesehatan, 1(1), 104-106.

Huda, M. (2014). Model-model Pengajaran dan Pembelajaran: Isu-isu Metodis dan Paradigmatis. Yogyakarta: Pustaka Pelajar.

Mahanal, S. (2007). Penerapan Pembelajaran Berdasarkan Masalah dengan Strategi Kooperatif Model STAD pada Mata Pelajaran Sains untuk Meningkatkan Kemampuan Berpikir Kritis. Jurnal Penelitian Kependidikan.

Men, F. E. (2017). Proses Berpikir Kritis Siswa SMA dalam Pengajuan Soal Matematika Berdasarkan Tingkat Kemampuan Matematika. Jurnal Matematika Kreatif-Inovatif, 8(2), 191-198.

Muh Tawil, L. (2013). Berpikir Kompleks dan Implementasinya dalam Pembelajaran IPA. Makasar: Badan Penerbit Universitas Negeri Makassar.

Padmapriya, P. V. (2015). Effectiveness of Self Learning Modules on Achievement in Biology Among Secondary School Students. International Journal of Education and Psychological Research, 4(2), 44-46.

Riduwan. (2013). Belajar Mudah Penelitian untuk Guru-Karyawan dan Peneliti Pemula. Bandung: Alfabeta.

Saglam, H. I. (2011). An Investigation on Teaching Material used in Social Studies Lesson. The Turkish Online Journal of Educational Technology, 1(10).

Sari, D. puspita. (2017). Respon siswa terhadap modul system eksresi manusia pada pembelajaran biologi kelas XI SMA. universitas tanjungpura.

Sujiono \& Widiyatmoko, A. (2014). Pengembangan Modul IPA Terpadu Berbasis Problem Based Learning Tema Gerak untuk Meningkatkan Kemampuan Berpikir Kritis Siswa. Unnes Science Education Journal, 3(3), 685-693.

Syahroni, M.W., Dewi, N. R., K. (2016). The Effect of Using DIGIMON (Science Digital Module) With Scientific Approach at the Visualization of Students' Independence and Learning Results. Jurnal Pendidikan IPA Indonesia, 5(1), 116-122. 
Wena, M. (2009). Strategi Pembelajaran Inovatif Kontemporer. Jakarta: Bumi aksara.

Windarti. (2015). Pengembangan Modul Pembelajaran Logika yang Memuat Pendidikan Karakter untuk Siswa Kelas X SMK. Jurnal Pendidikan Matematika, 10(1), 106-116. 